UDC 621.331.1

\title{
DIFFERENT CHARACTERISTICS BRAKE AUTOMOTIVE SYSTEM SALES RESEARCH MANUFACTURED BY ADDITIVE TECHNOLOGIES
}

\author{
Nesterenko Mykola ${ }^{1}$, Virchenko Viktor ${ }^{2 *}$, Shapoval Mykola ${ }^{3 *}$, Shokalo Artem ${ }^{4}$ \\ ${ }^{1}$ Poltava National Technical Yuri Kondratuyk University https://orcid.org/0000-0002-8961-2147 \\ ${ }^{2}$ Poltava National Technical Yuri Kondratuyk University https://orcid.org/0000-0002-5346-9545 \\ ${ }^{3}$ Poltava National Technical Yuri Kondratuyk University https://orcid.org/0000-0002-6943-7687 \\ ${ }^{4}$ Poltava National Technical Yuri Kondratuyk University https://orcid.org/0000-0002-7971-5724 \\ *Corresponding author E-mail: virchenko.viktor@gmail.com
}

Problems in designing hydraulic brake systems of cars have been analyzed. The study of the braking process has conducted considering the distribution of forces on the axles during braking. The general support model research and support geometric characteristics are developed. The calculation of the car brake system has been conducted that enables to determine the load on the caliper during the braking process and using graphic dependencies, and to determine the concentration of maximum stresses in the mounting areas of the support. Based on analytical studies in the Autodesk Fusion 360 3D Modeling program, a design has been implemented that features a smaller metal capacity at the expense of rational design and providing uniform strength across the entire surface. Adaptive technologies also significantly accelerate the production of new parts due to the lack of need for the production of auxiliary equipment, such as molds.

Keywords: brake system of the car, additive technologies, support.

\section{ДОСЛІДЖЕННЯ МІЦНІСНИХ ХАРАКТЕРИСТИК СУПОРТА ГАЛЬМІВНОЇ СИСТЕМИ АВТОМОБІЛЯ, ЩО ВИГОТОВЛЕНИЙ ШЛЯХОМ АДИТИВНИХ ТЕХНОЛОГІЙ}

\author{
Нестеренко М.П. ${ }^{1}$, Вірченко В.В. ${ }^{2 *}$, Шаповал М.В. ${ }^{2}$, Шокало А.В. ${ }^{4}$ \\ 1, 2,3, 4 Полтавський національний технічний університет імені Юрія Кондратюка \\ *Адреса для листування E-mail: virchenko.viktor@gmail.com
}

\begin{abstract}
Проаналізовано проблеми, що виникають при проектуванні гідравлічних гальмівних систем автомобілів. Запропоновано за допомогою адитивних технологій виготовити деталі гальмівної системи складної конфігурації, чого неможливо досягти іншими способами, наприклад виготовляти деталі, що мають внутрішні канали, порожнини, отвори складної форми і т. п. У деяких випадках завдяки цьому можна досягти зменшення кількості складальних вузлів, кріплень та відповідно зменшити розміри і масу вузлів. Виконано аналітичні дослідження процесу гальмування з урахуванням розподілу сил по осях автомобіля під час гальмування. Оскільки шина автомобіля є єдиним сполучним елементом між автомобілем та дорожньою поверхнею, у розрахунковій схемі розподілу сил, крім неї, представлено супорт і гальмівний диск. На прикладі супорта гальмівної системи автомобіля розроблено загальну модель дослідження міцнісних та геометричних характеристик деталі. Наведено розрахунок гальмівної системи автомобіля, який дозволяє визначити навантаження на супорт у процесі гальмування й за допомогою графічних залежностей визначити концентрацію максимальних напружень у місцях кріплення супорта. Базуючись на аналітичних дослідженнях, у програмі для 3D-моделювання Autodesk Fusion 360 реалізовано проект конструкції супорта, який відрізняється тим, що має меншу металоємність за рахунок раціонального дизайну та забезпечення однакового коефіцієнта міцності по всій поверхні. Запропоновано виготовлення такої деталі за допомогою адитивних технологій, що дозволяє досягти значної економії матеріалу завдяки багатошаровому нанесенню матеріалу й виключенню ряду технологічних операцій з обробітку заготовки. Адитивні технології також забезпечують високу технологічність виробництва та значно прискорюють виготовлення нових деталей через відсутність потреби у виробництві допоміжного обладнання, наприклад прес-форм.
\end{abstract}

Ключові слова: гальмівна система автомобіля, адитивні технології, супорт. 


\section{Introduction}

This publication topicality is based on the fact that it addresses the additive technologies use issue for the car parts manufacture. These technologies make it possible to produce parts with material rational distribution in the product volume. It reduces the mass of individual parts, and as a consequence, the mass of nodes and the whole vehicle.

Adaptive technologies enable to fabricate details of a complex configuration that cannot be achieved in other ways. For example, it becomes real to produce parts that have internal channels, cavities, holes of a complex shape, etc. In some cases, it is possible to achieve reduction in the number of assembly units, fasteners, and, accordingly, to reduce its dimensions and mass.

The research is aimed to improve the efficiency of the car by reducing its mass and to ensure its management safety. For detailed processing, the brake system of the car is chosen as such one that during the operation takes considerable load, and its serviceability and reliability influence the driving safety.

\section{Review of research sources and publications}

In the modern world, the complexity of hydraulic systems is quite high and constantly increasing (Fig. 1) $[7-8]$. The problem is that the usual methods of manufacturing parts cannot provide the manufacturing of those technical solutions that bring the given system to a new level. Due to manufacturing problems, engineers cannot implement innovative solutions for individual systems and components.

Nowadays, the parts used in hydraulic systems have a lot of weight. And there are concepts with innovative solutions that enable to make a breakthrough in the industry. The problem with designing the braking systems is that the braking system details have a complex structure of the internal channels where hydraulic losses occur. Due to existing manufacturing methods, the channels have a curvilinear shape, increasing the fluid resistance.

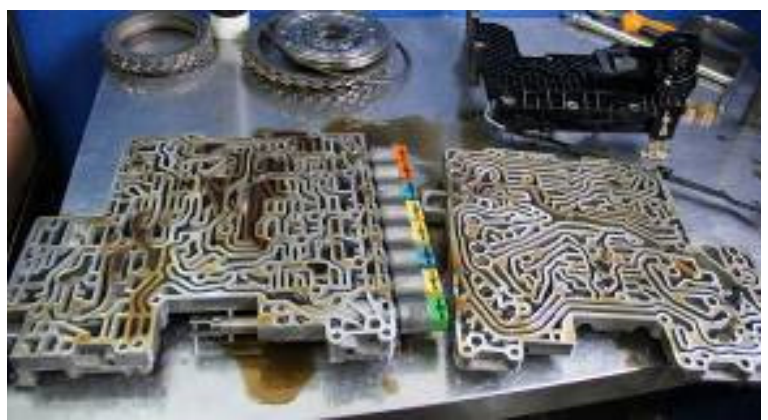

Figure 1 - BMW mechatronics

The additive manufacturing technologies development current level gives engineers freedom in designing parts and systems. With the help of additive technologies, any form of part and its internal structure can be made with high accuracy virtually (Fig. 2).

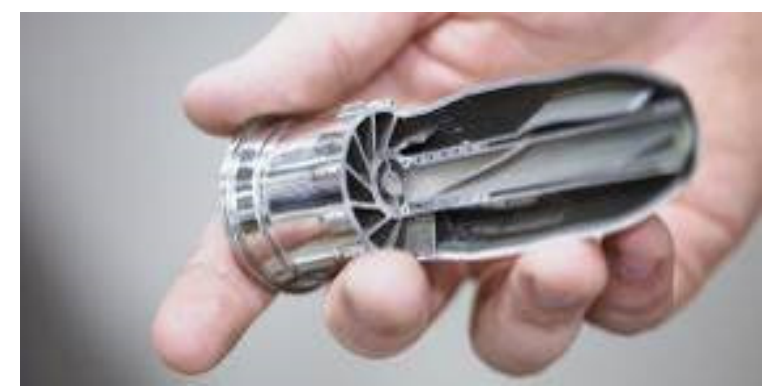

Figure 2 - An example of a component made by additive technology

Thus, by applying additive technology, it can be significantly reduced the weight of the brake system component and hydraulic losses throughout the system.

\section{Definition of unsolved aspects of the problem}

In modern braking systems of cars parts are used that have a significant metal content and an inflated strength across the entire surface. It is due to the lack of precision in the calculation of loads on the part and the organization of the technological process of their production, based on traditional foundry processes and metal cutting operations. In order to reduce the metal content of the car brake systems, today more precise calculations of loads on the part should be carried out and when designing modern graphic 3D simulation programs should be applied. It is expedient to produce details of the braking system of a complex configuration with the help of additive technologies that are difficult to obtain in other ways, for example, to produce parts having internal channels, cavities, holes of complex shape and so on.

\section{Problem statement}

The purpose of this article is to analyze the problems that arise during the design of cars hydraulic brake systems, the development of proposals for the calculation, 3D modeling and the application of modern additive technology in the system parts manufacture.

\section{Basic material and results}

Investigation of the braking the car process in most cases is an investigation of emergency braking and is reduced to determining the car speed and the brake path $[1,2,3]$. The tire is the only connecting element between the car and the road surface. Tire engagement is a decisive factor in road safety. So, in the distribution scheme, the support, the brake disk and the tire are depicted. In the process of braking the car instead of the torque, the braking torque is applied to the vehicle driving wheels, and instead of the traction effort, the braking force directed towards the reverse movement is substituted (Fig. 3).

The equation of motion in braking has the form

$$
-P_{2}=P_{f}+P_{w} \pm P_{i}-P_{j} \text {. }
$$

The amount of braking force is determined from expression 


$$
P_{2}=\gamma_{2} G_{k} g,
$$

where $\gamma_{2}$ - coefficient of specific braking force equal to the ratio of the braking forces sum occurring on all brake wheels to the weight of the vehicle $\left(\gamma_{2}=0.9\right)[1]$; $g-$ free fall acceleration.

Equation of Negative Acceleration Motion $j$

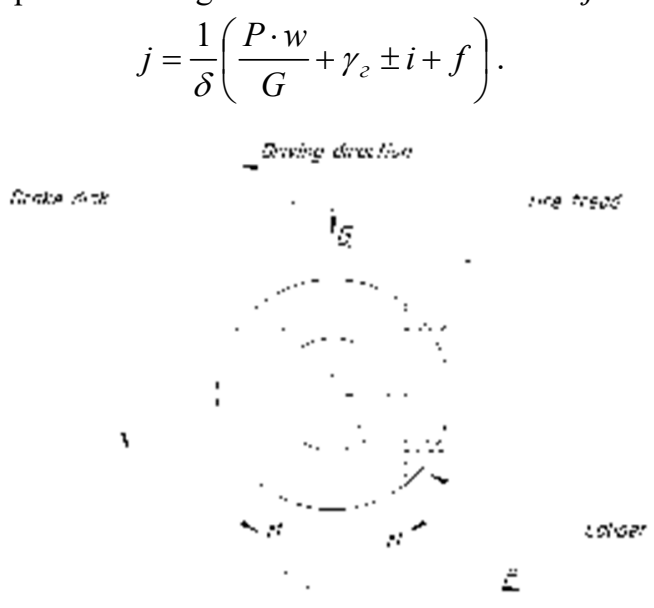

Figure 3 - Diagram of the distribution of forces during braking:

$M_{k r}$ - torque; $P_{q}$ - braking force; $M_{q}$ - braking torque; $G_{k}$ - the mass of the car falling on the wheel.

In modern cars with brakes on all wheels during emergency braking, the limiting value $\gamma_{t}$ equals the coefficient of tire adhesion with the cover $\varphi$ when driving on a road straight line and $\varphi_{1}-$ when moving along the curve.

Since during braking the car speed is sharply reduced, the air resistance can be neglected, then at $\delta=1$ (direct transmission)

$$
j=(\varphi \pm i+f) .
$$

Also, the value of the braking distance on which the driver can stop a car that moves at the rated speed is normalized. The path of complete braking can be found in the formula of the equilibrium motion

$$
v=\sqrt{2 a S_{m}},
$$

where $a$-absolute negative acceleration, $\mathrm{m} / \mathrm{s}^{2}$

$$
a=g \cdot j=g(\varphi \pm i+f) .
$$

Thus, the braking distance at $\mathrm{v}$ in $\mathrm{m} / \mathrm{s}$ is according to the formula

$$
S_{m}=\frac{v^{2} K_{e}}{2 g(\varphi \pm i+f)},
$$

where $K_{e}$ - the braking efficiency coefficient, considering that brakes state operation is equal to 1.2 for cars and 1.3 to 1.4 for trucks [1].

When braking a car on a horizontal road, an inertia force is formed $P_{i}$, applied to the center of gravity and equal to the sum of braking forces [1]. In this case, there is a redistribution of normal loads on the axes: the front loaded, and the rear axle is unloaded. In the static state of the vehicle, the load on the axle is determined by the distances a and $\mathrm{b}$ of the center of mass $O$ from the front and rear axles.

$$
G_{1}=G \frac{b}{L}, \quad G_{2}=G \frac{a}{L} .
$$

The normal reaction of the road acting on the front and rear wheels during braking is defined as

$$
R_{z 1}=G \frac{b+\varphi_{x} \cdot h}{L}, \quad R_{z 2}=1-\frac{\varphi_{x} \cdot h}{L} .
$$

Normal reactions $R_{z 1}$ and $R_{z 2}$ are perceived by the wheels during braking, differ from the loads that fall on the wheels in the static state. Redistribution of axial weights is estimated by the coefficients of variation of the responses $m_{p 1}, m_{p 2}$ that are equal to the horizontal road

$$
m_{p 1}=1+\frac{\varphi_{x} \cdot h}{b}, \quad m_{p 2}=1-\frac{\varphi_{x} \cdot h}{a} .
$$

Then the normal road responses are of the form

$$
R_{z 1}=m_{p 1} \cdot G_{1}, R_{z 2}=m_{p 2} \cdot G_{2} \cdot .
$$

When braking, the limit values of the reaction change coefficients are $1,5 \div 2,0$ front wheels and $0,5 \div 0,7$ - for the rear. The highest inhibition of the vehicle is achieved with the full use of clutch on all wheels, which is possible only on the road with optimum clutch ratio $\varphi_{\text {opt }}=0.4 \ldots 0.5[5]$.
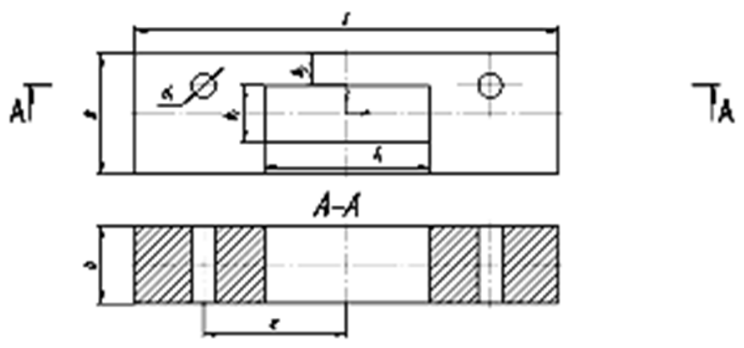

Figure 4 - Simplified support scheme

The carrier car accepts different types of loads, so it is necessary to examine it tension and compression. During the car parking on a sloping road, the caliper perceives static loads, and in the case of emergency braking - dynamic. The static load on the support is considered. For calculations, a simplified model of the support is suggested (Fig. 4).

When braking, the pads transmit the braking force $F$ from the brake disc to the servomotor at the point of contact. An equilibrium braking force and the reaction of the support in the force diagram are depicted (Fig. 5).

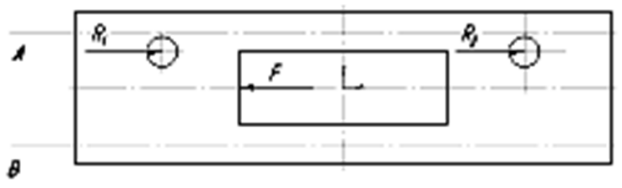

Figure 5 - Scheme of forces acting on the caliper and the axes $A$ and $B$ 
During normal stretching and compression in the cross sections of the support, normal stresses are distributed uniformly in the section [4]. They are calculated by the formula

$$
\sigma=\frac{N}{A}
$$

where $N$ - the longitudinal force;

$A$ - cross-sectional area.

Obviously, for tension and compression, the shape of the cross section does not affect the voltage value.

In the sections close to the places of forces application, the law of stresses distribution is more complicated, but using the boundary conditions mitigation principle, these deviations are neglected and it is considered that all cross sections of the cable voltage are evenly distributed and that in the section where along the axis concentrated force is applied to the beam, the values of the longitudinal force and stresses vary jumplike.

Since, the concentrated force and forces of the support reaction do not act on one axis, it is necessary to solve the equation of moments. Due to the fact that our model has a window in the middle, the equation relative to the two axes A and B is solved (Fig. 5).

Consequently, the equations of moments is:

$$
\begin{aligned}
& \sum M_{a}=0, \\
& \frac{-F\left(\frac{b_{1}}{2}+\frac{b_{2}}{2}\right)+R_{1}\left(b_{1}+\frac{b_{2}}{2}\right)+R_{2}\left(b_{1}+\frac{b_{2}}{2}\right)}{b_{1}+b_{2}}=N_{1} ; \\
& \frac{\sum M_{a}=0,}{-F\left(\frac{b_{1}}{2}+\frac{b_{2}}{2}\right)+R_{1} \frac{b_{2}}{2}+R_{2} \frac{b_{2}}{2}} \\
& \frac{b_{1}+b_{2}}{2}
\end{aligned}
$$

After calculations, we substitute the greatest moment obtained into (12) and find the stress.

This figure should not exceed the permissible stresses for the particular material from which the caliper is made

$$
\sigma \leq[\sigma]
$$

The cutoff forces also appear in the caliper, because the offsetting force transmitted from the brake disk is applied at a distance from the mounting points of the support.

It is believed that the tension stresses are distributed over the support section evenly. Then their value is equal, $\mathrm{Pa}$,

$$
\tau_{3 p}=\frac{N}{A_{3 p}},
$$

where $A_{3 p}$ - the cross-sectional area of the cut; $N$ - longitudinal force.

The resulting stresses should not exceed the permissible stresses on the cut for the selected material

$$
\tau_{3 p} \leq[\tau],
$$

For static loads, the permissible stresses on the cut are assumed to be approximately $70 \%$ of the permissible stresses on tension or compression for the same material

$$
[\tau]=0,7[\sigma] .
$$

For further calculations the prototype of the vehicle with the average Indicators - Daewoo Lanos 1.6 16V 2000 year of production is accepted.

Required technical specifications for calculations:

- allowable load on the front axle - $890 \mathrm{~kg}(445 \mathrm{~kg}$ per wheel);

- the size of tires $-175 / 50 \mathrm{R} 13$;

- the size of the brake disk - $236 \mathrm{~mm}$.

It is suggested the following dimensions of the simplified model of the support for checking the strength characteristics (Figure 3-4).

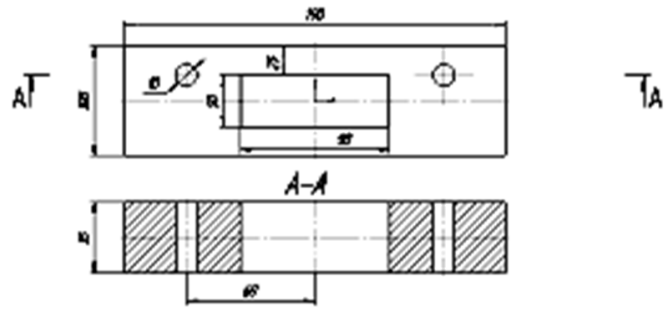

Figure 6 - Dimensions simplified model for calcu-
lating

Above-mentioned permissible load on the front wheel and the value of the coefficient of grip, are substituted in the formula (2) and the braking force is found that occurs on the front wheel $P_{2}=0.9 \cdot 445 \cdot 9.81=3929 \mathrm{H}$

Braking force acting on the $P_{c c}$ caliper, by the ratio shoulders (Fig. 7) is found. The size 175/50R13 has an external diameter of $500 \mathrm{~mm}$, so the braking force to the tire is $250 \mathrm{~mm}$. And the force acting on the support is applied in the center of the pads and has a shoulder to the center of the wheel $218 \mathrm{~mm}$.

Thus, the effort on the support $P_{c c}$ is equal to

$$
P_{c c}=3929 \cdot 250 / 218=4505 \mathrm{H} \text {. }
$$

Depending on the dependencies (1), (2), (3), (8), (9), $(10),(11)$, longitudinal forces are found, and from the equations of the moments (13) and (14) relative to the two axes $\mathrm{A}$ and $\mathrm{B}$, respectively, $N_{1}=901.13 \mathrm{H}$, $N_{2}=-901.13 \mathrm{H}$

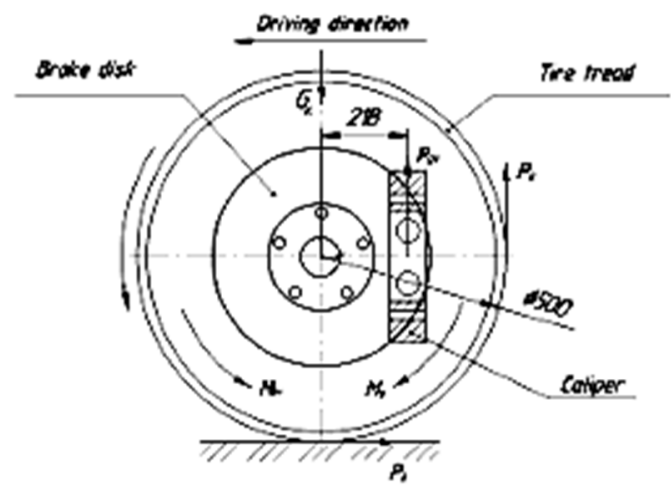

Figure 7 - Scheme of the ratio of the forces of the application of the arms 
It is found the maximum stresses in the section by substituting the maximum value of the force in the dependence (12)

$$
\sigma=\frac{901.13}{2 \cdot 0.025 \cdot 0.035}=514931 \mathrm{~Pa} .
$$

The stresses found are 0.51 MPs, but do not exceed the permissible stresses, which for aluminum are 30-80 MPa.

The distribution of the stresses along the $X, Y, Z$ axes is reduced to build a graph (Fig. 8).

According graphical dependencies stress distribution in cross section, their concentration in the area of mount is shown

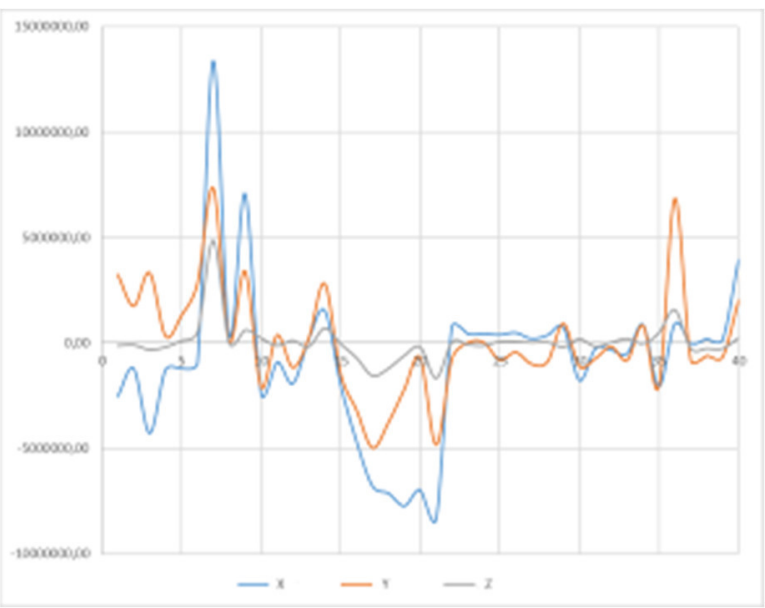

Figure 8 - Distribution of stresses along the axes $\mathrm{X}, \mathrm{Y}, \mathrm{Z}$

To ensure regular geometric characteristics, it is necessary to study the scheme displacement stress concentrators in their respective sections. The given data are summarized reducing to build a graph (Figure 9).

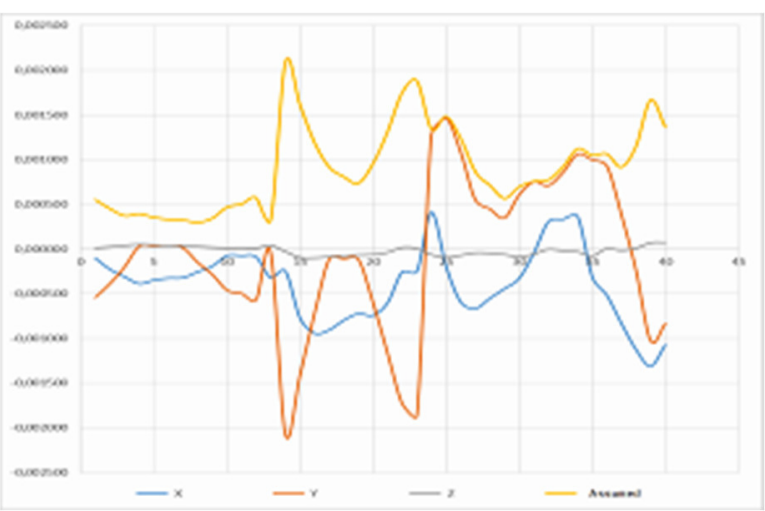

Figure 9 - Moving relative to the axes

Next, the tensile stresses in the section $\mathrm{Pa}$ are found and the cross section for the cut is calculated. The maximum calculated longitudinal force into formula IS substituted (16)

$$
\tau=\frac{901.13}{0.04 \cdot 0.035}=180200 .
$$

The result is converted into $\mathrm{MPa}, 0.18 \mathrm{MPa}$ is got.
By formula (18) the permissible voltages for aluminum on the cut, $\mathrm{MPa}$ is found

$$
[\tau]=0,7 \cdot 30=21
$$

Based on the results of analytical studies, the support design is suggested, which is based on the above-calculated overall dimensions, but with a significantly reduced metal capacity, which reduces its mass. This model of support is implemented in the program for 3D modeling Autodesk Fusion 360 (Figure 10).
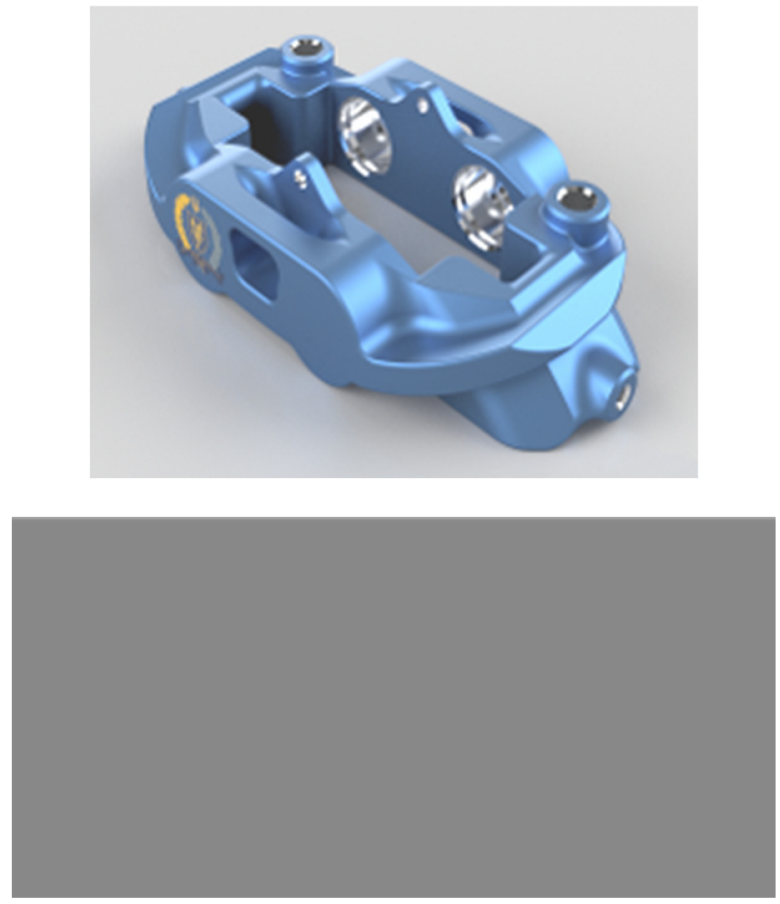

Figure 10 - The proposed design of the support

\section{Conclusions}

Execution of support proposed design strength research, which was made by means of additive technologies, enables to achieve the following results:

- the calculated section has an excess factor of strength, which adversely affects its mass; therefore, to reduce metal strength and weight, a rational design of the support is proposed;

- due to layered construction, considerable material savings are achieved in the manufacture and further processing of parts;

- adaptive technologies can significantly accelerate the production of new parts due to the fact that there is no need for the production of auxiliary equipment (e.g., molds etc.). Due to this, the speed of the entire production cycle increases significantly;

- it is possible to make details of complex configurations that cannot be made by other known methods. Due to this, parts with less weight without losing their durability can be made. 


\section{References}

1. Литвинов, А.С., Фаробин, Я. Е. (1989). Автомобиль. Теория эксплуатационных свойств. Москва: Машиностроение.

2. Иванов, В.Н. (2005). Все об активной и пассивной безопасности автомобиля. Москва: Астрел-АСТ.

3. Pang, W. (2012). Study on the improvement of automobile braking performance. Journal of East China Normal University, 2, 19-21.

4. Ruscio, D., Ciceri, M.R. \& Biassoni, F. (2015). How does a collision warning system shape drivers brake response time? The influence and automation complacency on real life emergency braking. Accident analysis and prevention, 77, 72-81.

https://doi.org/10.1016/j.aap.2015.01.018

5. Markkula, G., Engstrom, J., Loclin, J., Bargaman, J. \& Victor, T. (2016). A farewell to brake reaction times? Kinematics dependent brake response in naturalistic rear end emergencies. Accident Analysis and Prevention, 95, 209- 226.

https://doi.org/10.1016/j.aap.2016.07.007

6. Song, J. \& Che, W.S. (2009). Comparison between braking and steering yaw moment controllers considering ABS control aspects. Mechatronics, 19(7), 1126-1133.

https://doi.org/10.1016/j.mechatronics.2008.11.011

7. Badea-Romero, A., Paez, F.J., Furones, A., Barrios, J.M. \& de-Miguel, J.L. (2013). Assessing the benefits of the brake assist system for pedestrian injury mitigation through real world accident investigations. Safety science, 53, 19-201.

https://doi.org/10.1016/j.ssci.2012.10.004

8. Milanés V., González C., Naranjo J.E., Onieva E. \& de Pedro T. (2010). Assessing the benefits of the brake assist system for pedestrian injury mitigation through real world accident investigations. International Journal of Automotive Technology, 11(1), 89-95.

https://doi.org/10.1007/s12239-010-0012-6

9. Назаренко, I.I., Нестеренко, М.П. (2015). Методика досліджень загальної динамічної моделі «технологічна машина для будівельної індустрії - оброблюване середовище». Техніка будівництва, 34, 4-11.
1. Litvinov, A.S. \& Farobin, E.E. (1989). The car. The theory of operational properties. Moscow: Mechanical Engineering.

2. Ivanov, V.N. (2005). It's all about active and passive vehicle safety. Moscow: Astrel-AST.

3. Pang, W. (2012). Study on the improvement of automobile braking performance. Journal of East China Normal University, 2, 19-21.

4. Ruscio, D., Ciceri, M.R. \& Biassoni, F. (2015). How does a collision warning system shape drivers brake response time? The influence and automation complacency on real life emergency braking. Accident analysis and prevention, 77, 72-81. https://doi.org/10.1016/j.aap.2015.01.018

5. Markkula, G., Engstrom, J., Loclin, J., Bargaman, J. \& Victor, T. (2016). A farewell to brake reaction times? Kinematics dependent brake response in naturalistic rear end emergencies. Accident Analysis and Prevention, 95, 209- 226.

https://doi.org/10.1016/j.aap.2016.07.007

6. Song, J. \& Che, W.S. (2009). Comparison between braking and steering yaw moment controllers considering ABS control aspects. Mechatronics, 19(7), 1126-1133.

https://doi.org/10.1016/j.mechatronics.2008.11.011

7. Badea-Romero, A., Paez, F.J., Furones, A., Barrios, J.M. \& de-Miguel, J.L. (2013). Assessing the benefits of the brake assist system for pedestrian injury mitigation through real world accident investigations. Safety science, 53, 19-201. https://doi.org/10.1016/j.ssci.2012.10.004

8. Milanés V., González C., Naranjo J.E., Onieva E. \& de Pedro T. (2010). Assessing the benefits of the brake assist system for pedestrian injury mitigation through real world accident investigations. International Journal of Automotive Technology, 11(1), 89-95.

https://doi.org/10.1007/s12239-010-0012-6

9. Nazarenko, I.I. \& Nesterenko, M.P. (2015). Research methodology of the general dynamic model "technological machine for construction industry - processed environment". Construction Engineering, 34, 4-11. 